\title{
Empirical Methodology and Legal Scholarship
}

\author{
Jack Goldsmith† \\ Adrian Vermeule $\dagger$
}

In The Rules of Inference ("Rules"), Lee Epstein and Gary King argue that all empirical and causal assertions in all legal scholarshipincluding doctrinal, normative, and interpretive scholarship that asserts subsidiary empirical and causal claims-should follow a unitary approach to inference, one that is grounded in the logic of statistics. From that premise, they advance a sweeping indictment of legal scholarship and its supporting institutions, claiming that every article in their large data pool violates at least one rule of inference ${ }^{2}$ and urging a radical reorientation of legal education. ${ }^{3}$

At some level of generality, it is hard to disagree with the spirit of Epstein and King's complaints. Scholarship generally, not only in law or political science, should ground its empirical assertions in warranted inferences from sound evidence, should admit to causal and empirical uncertainty where it exists, should avoid tendentiousness and selection bias, and should follow the best statistical practices when making statistical claims. Lawyers and judges, and indeed educated people generally, would benefit from a basic knowledge of statistical methods. Putting aside the opportunity costs of statistical training (an issue to which we return below), greater attention to the rules of inference would, when appropriate, improve legal scholarship.

We nonetheless reject much of Epstein and King's indictment of legal scholarship. We begin in Part I by identifying a broad domain of legal scholarship for which the rules of inference lack obvious relevance. As is unsurprising for outsiders, Epstein and King overlook that legal scholarship frequently pursues doctrinal, interpretive, and normative purposes rather than empirical ones. Legal scholars often are just playing a different game than the empiricists play, which means that no amount of insistence on the empiricists' rules can indict legal scholarship-any more than strict adherence to the rules of baseball

$\dagger$ Professor of Law, The University of Chicago.

t† Professor of Law, The University of Chicago.

We thank Douglas Baird, Richard Epstein, Jake Gersen, Kate Kraus, Daryl Levinson, Doug Lichtman, Martha Nussbaum, Eric Posner, Richard Posner, Duncan Snidal, Cass Sunstein, Steve Walt, and David Weisbach for comments and conversation.

1 Lee Epstein and Gary King, The Rules of Inference, 69 U Chi L Rev 1 (2002).

Id at 11.

3 Id at 114-33. 
supports an indictment of cricket. Epstein and King miss this point because their empirical methodology blinds them to legal scholarship's internal perspective. Epstein and King's external perspective-if valid-might cause legal scholars to see their practices in a new and interesting light. But in many domains of legal scholarship, it provides no basis for persuading insiders to accept Epstein and King's methodological counsels.

Having narrowed the field of potential relevance, we next question the privileged status of Epstein and King's rules of inference even within political science, much less in other domains. Epstein and King give the impression that their article extends uncontroversial methods from political science to law. In fact, as we show in Part II, Epstein and King's prescriptions are contested even in their own discipline. There simply are not "Rules of Inference" in the sense of universally agreedupon methods of empirical analysis.

Even granting the relevance and legitimacy of the rules of inference, Part III contains a pragmatic critique of Epstein and King's prescriptions. If empirical research were costless, Epstein and King's prescriptions would be sensible. But given constraints on time, information, expertise, and research funds, academics face inevitable tradeoffs between rigor and accuracy, on the one hand, and timeliness, relevance, and utility, on the other. This tradeoff is especially pointed for disciplines that, like law, are professionally and practically involved in the business of courts and other governmental institutions that must constantly reach decisions despite profound empirical uncertainty. A warning sign for Epstein and King is that their own article contains a host of embedded empirical and causal assertions that violate the rules of inference. This fact is significant not because it exposes Epstein and King as inconsistent or hypocritical, but because it underscores that scholarship must necessarily proceed on the basis of unproven empirical assumptions if it is to proceed at all.

\section{RELEVANCE}

Epstein and King lack a normative account of the aims of legal scholarship, and the lack of such an account deprives them of the normative baseline they need to ground their criticisms. The reader of Epstein and King's 133-page article will find almost nothing that speaks to the simple question, "What is legal scholarship for?" Much of the time Epstein and King implicitly assume that legal scholarship ought to relate to the legal system in the same way that political science or government departments relate to the political system generally. On this view, legal scholars are, at present, just political scientists who (1) study a limited subset of political institutions, namely those that produce and enforce legal rules, and (2) lack the empirical and 
methodological tools that real political scientists possess. The needed reforms will improve the legal academy's methodological skills, while leaving the legal academy confined to its present substantive domain. Legal scholars should be junior-varsity political scientists-and, as we discuss in the next Part, political scientists of a particularly narrow stripe.

But there is an entirely different picture of the aims of legal scholarship. In a large domain, it is not true that legal scholars try to do just what political scientists do, only less successfully. Often, legal scholars try to do other things entirely, and at least sometimes do them rather well. Those other things include making doctrinal, interpretive, and normative arguments. The legal academy supplies vocational rather than scientific training; law schools usually produce lawyers, not graduate students; and legal scholars often write in the lawyer's style rather than in the empiricist's because they are participants in, not just students of, the legal system's practices.

The substance of much legal scholarship is doctrinal, interpretive, and normative. Subgenres in this category include articles and books that attempt to reconcile or distinguish lines of precedent displaying internal tensions; that provide conceptual analysis of the internal logic of statutes, cases, and other materials; and that provide novel readings of canonical legal sources. The best legal scholarship combines these features, fitting confused canonical materials together in a coherent way and presenting the materials in a normatively attractive light. Work in this vein contains no empirical claims in any important or contestable sense-at least not if "contestable" is defined by reference to the internal consensus of legal academics. As we discuss below, any scholarly community presupposes some degree of consensus on shared premises, empirical and otherwise.

Doctrinal, interpretive, and normative legal scholarship seeks to persuade, which means that the lawyer's style is often largely rhetorical. Epstein and King describe lawyerly rhetoric as "political persuasion," in a tone suggesting that Epstein and King equate persuasion with sophistry. But Epstein and King overlook that the rhetorical style is a mixed bag of vice and virtue. The vice is that much legal scholarship is advocacy scholarship, and therefore rhetorical in the condemnatory sense: it is tendentious, sloppily or even deceptively reasoned, and rests upon unsubstantiated factual claims or the sort of empirical shibboleths that circulate in law schools (for example, that disagree-

4 There are, of course, many other aspects to legal scholarship, many of which are not touched by Epstein and King's critique. In these short comments we focus our analysis on these three aims.

5 Epstein and King, $69 \mathrm{U}$ Chi L Rev at 9-10 n 23 (cited in note 1).

6 See Richard A. Posner, Overcoming Law 73-74, 517-30 (Harvard 1995). 
ment among the justices harms the Supreme Court's public standing). The last point is, as we have said, the kernel of truth in Epstein and King's position.

But there is a sense in which "rhetorical" need not be a term of condemnation. Rhetoric is often a more effective tool of persuasion than is, for example, regression analysis, because successful rhetoric is accessible, vivid, and mixes positive, interpretive, and normative claims in richly textured ways. Good legal scholarship is effective precisely because it displays these rhetorical traits. At its best, persuasive legal scholarship displays a power to elucidate the logic of doctrinal practices in enlightening ways, to engage audiences, and to motivate legal and social change-a power usually lacking in the pallid output of statistical empiricism.

Epstein and King briefly nod to some of these points in a buried footnote, but the rest of their article shows that they have failed to internalize their implications. They say that persuasion and advocacy are appropriate to the courtroom, but that "the faculty commons" is a place in which "the truth, and not just a particular version of it, matters." In Part II we question their equation of valid inference with statistical inference. But even on its own terms, Epstein and King's complaint elides a critical possibility: the contest of "particular versions" of truth ventilated by legal articles that are tendentious when taken separately may, at the systemic level, produce increasingly accurate approximations of truth, as scholar-advocates criticize the work of opposing camps. That possibility transposes the standard justification for the adversary system from the courtroom to the faculty commons, collapsing one of the loadbearing walls in Epstein and King's construct.

The point here is not to defend an adversarial picture of legal scholarship. The point is that Epstein and King's distinction rests on the same fallacy as the simplistic complaint that the adversarial system of adjudication, as opposed to the inquisitorial system, distorts facts. True, lawyers in the courtroom shade facts and law to accord with their desired outcomes. But it is possible, and indeed, for better or worse, it is the premise of our litigation system, that the aggregate effect of individual tendentiousness is a fully rounded picture of the truth. The same aggregate effect may hold for tendentious legal scholarship. In both the academic and courtroom settings, there is a systemlevel justification for the competitive production of evidence that Epstein and King's simple critique assumes away.

The consequence of Epstein and King's failure to appreciate the doctrinal, interpretive, and normative cast of much legal scholarship is

7 Epstein and King, 69 U Chi L Rev at 9-10 n 23 (cited in note 1).

8 Id at 10. 
that an air of unreality, of Martian anthropology, hovers over the article. Amar and Widawsky famously argued that the Thirteenth Amendment prohibits privately initiated child abuse as a form of "slavery [or] involuntary servitude." Epstein and King say that the Amar/Widawsky theory "surely ... lends itself to several testable predictions" and "observable implications",; for example, they claim that "if the term 'slavery' is broad enough to cover child abuse, then we might expect to find traces of that sentiment in the historical, legislative, and judicial records." There is a misstep here, akin to the small but jarring mistakes that speakers of a second language constantly commit: Amar is a textualist, not an originalist per se, and would probably think such evidence about the specific intent of contemporaneous actors marginally relevant to the task of developing a coherent account of the text's implicit structure and deep commitments.

But the larger gaffe is to think that works like Amar and Widawsky's are making "empirical" claims in any sense recognizable to political scientists. The claim that "child abuse is slavery" is not a statement of fact like "Hyde Park is in Chicago." It is an interpretive and normative program-legal actors should count child abuse as slavery for purposes of enforcing the Thirteenth Amendmentpresented in the form of an arresting metaphor. Legal scholarship sometimes deploys such metaphors to disrupt the audience's assumptions, in the hopes of presenting old practices in a new light and thereby stirring reform. This is an example of the socially productive power of rhetoric to reorient perceptions. After the Amar/Widawsky article, we notice, even if we choose to reject, uncomfortable analogies between practices that previously seemed unconnected.

In a similar vein, Epstein and King seemingly assume throughout that statements such as "the Framers thought $X$ " are testable claims of fact that might at least in principle be quantified by counting quotations in Farrand or in the ratification debates. More often in legal literature, though, such claims should be taken as shorthand for complex interpretive accounts of sources that have attained canonical status within the legal culture. Epstein and King's failure to recognize this point commits them, no doubt unwittingly, to a narrow and controversial version of specific-intention originalism, one now widely disavowed by most originalist academics, ${ }^{12}$ and causes them to equate naively canonical and noncanonical sources. On Epstein and King's

9 Akhil Reed Amar and Daniel Widawsky, Child Abuse as Slavery: A Thirteenth Amendment Response to DeShaney, 105 Harv L Rev 1359 (1992).

10 Epstein and King, 69 U Chi L Rev at 73 (cited in note 1).

11 Id.

12 See, for example, Steven G. Calabresi and Saikrishna B. Prakash, The President's Power to Execute the Laws, 104 Yale L J 541, 552 \& n 35 (1994). 
methods, a statement by James Madison counts for no more than a statement by other signers of the Constitution, including such unknowns as Gunning Bedford of Delaware, Richard Dobbs Spaight from North Carolina, or William Few of Georgia. ${ }^{13}$ The difference between Madison and the unknowns is the sort of soft cultural variable that the external perspective finds it especially difficult to appreciate.

For a final and somewhat more complicated example, consider the empirical controversy over whether the death penalty has a deterrent effect. Legal scholars continue to cite Isaac Ehrlich's famous but methodologically suspect study; Epstein and King use this as an example of "the staying power of flawed and discredited legal studies.". As good empiricists, however, Epstein and King should ask themselves whether there is an explanation (other than tendentiousness or stupidity) for legal scholars' persistence in invoking Ehrlich's work. Dan Kahan, for example, argues that legal scholars use the language of deterrence in the hope that it will present an appearance of neutrality and dampen intractable conflict over the philosophy of punishment. ${ }^{15}$ On this view, it is no more important that the relevant studies are inaccurate or outdated than it is important to a lawyer that the phrase "hung jury" is an archaic and obscure metaphor.

But it may be asking too much of external observers, not situated within and saturated by the debates internal to the legal discourse about capital punishment, to imagine even such an explanation. Our point here is not to endorse tendentious distortions of fact. Our point is simply to call into question Epstein and King's resolutely externalist approach to legal scholarship; the Martian anthropologist may end up being a worse, rather than better, empiricist, because the Martian anthropologist's inability to participate in and identify empathetically with the practice of legal discourse may radically contract the range of hypotheses that seem plausible candidates for testing. That possibility is central to a long-running methodological debate in anthropology, political science, and many other disciplines, between scholars of Epstein and King's externalist stripe, on the one hand, and hermeneutic or interpretive social theorists, on the other. The interpretive camp argues that empiricists must become, to the extent possible, participants who interpret cultural practices from the inside. ${ }^{16}$ By assuming away the interpretivists' view at the outset, Epstein and King commit them-

13 See US Const signatories.

14 Epstein and King, 69 U Chi L Rev at 17 n 42 (cited in note 1).

15 See Dan M. Kahan, The Secret Ambition of Deterrence, 113 Harv L Rev 413 (1999).

16 See, for example, Daniel Little, Varieties of Social Explanation: An Introduction to the Philosophy of Social Science (Westview 1991); Clifford Geertz, The Interpretation of Cultures (Basic 1973). 
selves to controversial assumptions that narrow the audience for, and the relevance of, their supposedly technical critique.

\section{THE RULES OF INFERENCE?}

This points to a different critique of Rules. Epstein and King complain that legal scholarship displays "little awareness of, much less compliance with, the rules of inference that guide empirical research in the social and natural sciences." A reader of Rules uninformed of longstanding methodological debates in social sciences might be forgiven for thinking that there is a single, uncontroversial approach to inference across disciplines that is essentially statistical. Rules not only assumes away the possibility of normative and interpretive political and social theory, but also, even within the non-interpretive camp, assumes the hotly contested proposition that statistical methods of inference apply equally to large-number empirical claims, on the one hand, and qualitative case-study work, on the other.

This assumption requires an extended defense not provided here by Epstein and King, for there is a vigorous contemporary debate about the value of statistical approaches to inference in small-number case studies. We cannot do better here than to point the reader to criticisms of the statistical approach, advanced in the highly respected peer-reviewed journals that Epstein and King praise, by political scientists with impressive methodological credentials. ${ }^{18}$ The essential point of this critique is that the statistical worldview does not translate cleanly to the single (or small-number) case study, where a detailed contextual analysis can often uncover causal and other explanatory mechanisms that statistical correlation cannot capture.

For similar reasons, proponents of the statistical approach find it puzzling that certain cases receive disproportionate attention, both in political science and in law, because those cases have attained canonical status in the relevant academic community, or have become focal points around which academic communities organize their debates. Epstein and King have a tin ear for this phenomenon, as their critique of Sklansky's work on the Fourth Amendment shows. ${ }^{19}$ Sklansky claims that the Supreme Court's search-and-seizure jurisprudence has recently taken an originalist turn and supports his claim by pointing to

17 Epstein and King, 69 U Chi L Rev at 6 (cited in note 1) (emphasis added).

18 See, for example, Timothy J. McKeown, Case Studies and the Statistical Worldview: Review of King, Keohane, and Verba's Designing Social Inquiry: Scientific Inference in Qualitative Research, 53 Intl Org 161 (1999); Mark I. Lichbach, ed, Review Symposium: The QualitativeQuantitative Disputation: Gary King, Robert O. Keohane, and Sidney Verba's Designing Social Inquiry: Scientific Inference in Qualitative Research, 89 Am Polit Sci Rev 454 (1995).

19 Epstein and King, $69 \mathrm{U}$ Chi L Rev at 32-34 (cited in note 1). 
a set of prominent recent cases. ${ }^{20}$ Epstein and King complain that Sklansky examines only eleven of the fifty-four cases the Court decided in the relevant period, and demand that he demonstrate that his sample fairly represents the whole set. ${ }^{21}$ But that complaint is about as impressive as questioning the empirical importance of substantive due process on the ground that the Court has sustained such claims in only a few areas-abortion, contraception, and similar contexts-while rejecting it in many others. The legal and cultural salience of Roe $v$ Wade $e^{z}$ far outruns its statistical significance.

A similar shortcoming of Epstein and King's worldview is apparent in their insistence on a statistical approach to history. There are many examples of this in Rules. Consider their criticism of Fisher's article on the rise of plea bargaining. ${ }^{23}$ Epstein and King charge Fisher with failing to demonstrate what his detailed case study of plea bargaining in one tier of a Massachusetts county's judicial system reveals about the rise of plea bargaining in America. Just as in political science, where case studies can be valuable because they uncover previously unknown chains of causation, ${ }^{25}$ so too the weaving of an interesting and coherent narrative in one jurisdiction can reveal previously unknown patterns or explanations in broader contexts. Presumably, Fisher could have made thin observations about many jurisdictions, but instead he chose to make thick observations about one. The only reason for rejecting the latter strategy out of hand is that Epstein and King want to remake all other disciplines in the image of largenumber statistical empiricism. Epstein and King's statistical approach to history would startle historians trained in their discipline's qualitative and narrative approach to inference.

\section{TRADEOFFS}

We turn, finally, to a pragmatic critique of Epstein and King's project. Epstein and King's indictment of legal scholarship is comprehensive and severe. They claim that "every single [law review article they read] violates at least one of the rules" of inference. ${ }^{26}$ They appear to conclude that all such legal scholarship is illegitimate andbecause it may affect public policy-pernicious. ${ }^{27}$ The problem is that

20 David A. Sklansky, The Fourth Amendment and Common Law, 100 Colum L Rev 1739 , 1745-74 (2000).

21 See Epstein and King, $69 \mathrm{U}$ Chi L Rev at 3, 32 (cited in note 1).

22410 US 113 (1973).

23 George Fisher, Plea Bargaining's Triumph, 109 Yale L J 857 (2000).

24 Epstein and King, $69 \mathrm{U}$ Chi L Rev at 101-02 (cited in note 1).

25 See McKeown, 53 Intl Org at 174 (cited in note 18).

26 Epstein and King, $69 \mathrm{U}$ Chi L Rev at 17 (cited in note 1).

27 See, for example, id ("Since [ ] every single [article analyzed has] the potential to find [its] way into a court case, an administrative proceeding, or a legislative hearing, we can only 
the same indictment can be made of Rules itself. Throughout Rules, Epstein and King frequently make or assume a variety of causal or descriptive empirical claims that violate the very rules of inference that they urge the legal community to embrace. This is important not because it evinces inconsistency or hypocrisy on their part. Rather, it is important because it demonstrates a fundamental constraint of scholarship that Epstein and King discount-namely, the tradeoff between (certain conceptions of) accuracy and rigor, on the one hand, and timeliness and relevance, on the other.

Consider Epstein and King's astounding claim that legal scholarship is not a social enterprise, and that legal scholars do not view it as a social enterprise. ${ }^{23}$ Epstein and King mention three "telltale signs of [legal scholars'] disinterest" in the social aspects of scholarshipnonadherence to Epstein and King's strict criteria for replication of research, the relative lack of coauthored scholarship, and the relative absence of peer-reviewed law journals. ${ }^{29}$ How does one assess these claims? Epstein and King might simply believe that scholarship as a social enterprise is scholarship characterized by these three characteristics. But this would make their claim an uninteresting definitional stop, leaving them open to the rejoinder that legal scholars define sociability differently.

The more charitable interpretation is that Epstein and King are making a causal empirical claim. They appear to believe that legal scholars do not take seriously the social aspects of scholarshipengaging the work of other scholars, building on it, criticizing it, working through problems together-because they do not attend to replication standards, do not coauthor, and do not publish in peer-edited journals. Or perhaps they are making the opposite causal claim: legal scholars do not engage in these three practices because they believe scholarship should proceed in isolation. It does not matter which way the purported causality runs, for Epstein and King do not provide a shred of empirical evidence for either causal claim. Moreover, in the course of making the claims, Epstein and King commit a host of sins they decry. They certainly have not done what they insist legal scholars do-namely, "maximiz[ing] their vulnerability" by considering "rival hypotheses" for the practices they bemoan. ${ }^{30}$ They fail to consider other indicia of scholarly sociability - workshops, co-teaching, draftswapping, written and oral comments, lunch conversations, symposia, etc., all of which are in our experience more present in law schools

imagine the serious consequences for public policy (not to mention for the development of knowledge) that may have already resulted-or still may result.").

28 Id at 45.

29 Id at $45-49$.

30 Id at 76. 
than in political science departments. ${ }^{31}$ And they read evidence of sociability in legal scholarship uncharitably when they assert-again, without the attention to the rules of inference that they claim is so crucial-that extravagant footnoting and lengthy "thank you" footnotes are evidence of the flabbiness, rather than the sociability, of legal scholarship. ${ }^{32}$ Why is coauthoring evidence of sociability, while thanking colleagues for comments is not?

Moreover, Epstein and King never consider why lawyers committed to legal scholarship as a social enterprise might with good reason avoid the institutional practices that Epstein and King praise. For example, while there is much to be said for peer-reviewed journals, there are reasons not to favor them as well. One has to do with the lengthy delay-sometimes years-between writing and publication that inheres in a peer-review system. Whatever value the peer-review system brings thus must be traded off against the costs of untimeliness and delay. It is just such costs that have led physicists-scholars who undoubtedly share Epstein and King's commitment to statistical method-to jettison the ex ante peer review system for all purposes but tenure review, and instead to publish their work online for immediate circulation, letting the market sort out quality ex post. ${ }^{33}$

Peer review systems also raise the concern that senior scholars favor like-minded scholarship and choke off the channels of intellectual change and development. Indeed, over one hundred political scientists, many of them leaders in their subfields, recently signed a letter complaining that the editorial board of the American Political Science Review (the discipline's "flagship" publication ${ }^{34}$ ) is dominated by scholars "intensely focused on technical methods at the expense of the great, substantive political questions that actually intrigue" many political scientists. ${ }^{35}$ This letter went on to state that "[i]t is very unfortunate that deeply committed political scientists genuinely believe, whether rightly or wrongly, that they cannot criticize the status quo safely without the cloak of anonymity." ${ }^{, 36}$ The concerns raised by these political scientists have special salience in a discipline that, like law,

31 Even if we are wrong in this conjecture, Epstein and King should have, by their own criteria, considered and rejected these and other possible "telltale signs" of sociability in legal scholarship before making such a pointed claim.

32 Epstein and King, $69 \mathrm{U}$ Chi L Rev at 45, 127 (cited in note 1).

33 See E-Print Archive, available online at <xxx.lanl.gov> (visited Nov 19, 2001). We thank Kate Kraus for bringing this practice to our attention.

34 Epstein and King, $69 \mathrm{U}$ Chi L Rev at 45 (cited in note 1).

35 See Rogers M. Smith, et al, An Open Letter to the APSA Leadership and Members, 33 PS: Polit Sci and Polit 735, 735 (Dec 2000). For another complaint about this trend in political science, see Jonathan Cohn, Irrational Exuberance: When Did Political Science Forget about Politics?, New Republic 25, 31 (Oct 25, 1999).

36 Rogers M. Smith, et al, 33 PS: Polit Sci and Polit at 736 (cited in note 35). 
lacks a general consensus about the means and ends of scholarship, and that is ideologically charged. These concerns are attenuated in a publication system that is, as in law, decentralized and not dominated by scholars with particular commitments and agendas.

Rules is filled with many other empirical whoppers and inferential bloopers, including: the flatly erroneous claim that there is not a single "law review article[ ] devoted to improving, understanding, explicating, or adapting the rules of inference"; ${ }^{37}$ the assertion that legal scholars do not cite relevant literatures (a claim at odds with their complaint about lawyers' string citations, and, more importantly, one supported, contrary to their principles, only by a string citation and a few examples that reek of selection bias) ${ }^{33}$ the unsubstantiated, question-begging, and much-criticized claim within political science that "[o]ther fields seem to benefit from devoting sustained attention to their methodological problems"; ${ }^{39}$ and the amusing but groundless assertion that attention to the rules of inference will increase legal scholars' readership. ${ }^{40}$ There are many other examples.

Epstein and King might respond by claiming that their criticisms of legal scholarship are not made at this level of empirical detail. We doubt this is true, but it is impossible to tell from Rules. The problems begin with Epstein and King's description of their "supplemental" data set of "empirical articles from six top law reviews." "We have no idea whether "empirical articles" include articles with the word "empirical" in the title (the criterion for the initial data set), or articles that are "empirical" in the sense that they include any "evidence about the world based on observation or experience." ${ }^{42}$ Setting aside problems in the description of the data pool, Epstein and King "do not tabulate the particular types of mistakes" they identified, do not code their data (because it was too hard to do), and "summarize [their] survey ... without explicit references." ${ }^{43}$ These are unfortunate omissions in an article that stresses over and over again that "[r]esearch must be replicable." As Epstein and King insist: "[A]nother researcher should be able to understand, evaluate, build on, and reproduce the research

37 Epstein and King, $69 \mathrm{U}$ Chi L Rev at 11 (cited in note 1). To take one of many counterexamples of which Epstein and King appear ignorant, see George L. Priest and Benjamin Klein, The Selection of Disputes for Litigation, $13 \mathrm{~J}$ Legal Stud 1 (1984), which argues that settlement effects make the pool of litigated cases an unrepresentative sample of legal issues.

38 See Epstein and King, $69 \mathrm{U}$ Chi L Rev at 57 (cited in note 1).

39 Id at 18.

40 See id at 59.

41 Id at 16.

42 Id at 2.

43 Id at 15 \& $n 36$.

44 See, for example, id at 38. 
without any additional information from the author." ${ }^{45}$ And yet Epstein and King provide no way for other scholars to assess their claims about the sorry methodological shape of legal scholarship. They do not, for example, "explain why they marshal particular pieces of evidence and neglect others," thereby making it impossible to "reproduce [their study] without talking to the authors." gest that we question their methodological rigor; they have extraordinary reputations as rigorous empirical scientists. But Epstein and King vehemently warn that "appeal-to-authority ... is wholly irrelevant to valid inference." $"$ is

We do not believe that Epstein and King's violations of their own rules demonstrate the invalidity of these rules. Rather, we point out these violations for three reasons. First, doing so demonstrates that in any work of scholarship, some empirical claims must be taken as given so that others can be questioned. In the normal science of day-to-day scholarly work, an intellectual community necessarily indulges innumerable shared assumptions-including shared empirical assumptions - that do not require empirical demonstration. Of course, scholarship sometimes questions these assumptions, and sometimes an external perspective can help shine light on empirical premises that are unwarranted. But the incessant demand for empirical confirmation reveals incomprehension of the assumptions demanded by the internal perspective of any practice.

Second, Epstein and King's violations of their rules of inference show that scholarship can be valuable even when it contains problematic empirical assertions. To repeat a point we made in the introduction: we believe that there is much valuable criticism of legal scholarship in Rules. And we have no doubt that the article will have a beneficial influence on legal scholarship, both in introducing some lawyers to the rules of inference, and in sparking a healthy debate. The point here is that Rules is not rendered valueless because it contains many unfounded empirical claims. The same, we think, is true of the legal scholarship that Epstein and King criticize.

Third, and most importantly, Epstein and King's violations of their own rules illuminate important practical constraints on scholarship that they ignore. Because of limited resources (in terms of time, research funds, information, expertise, etc.), there is a tradeoff be-

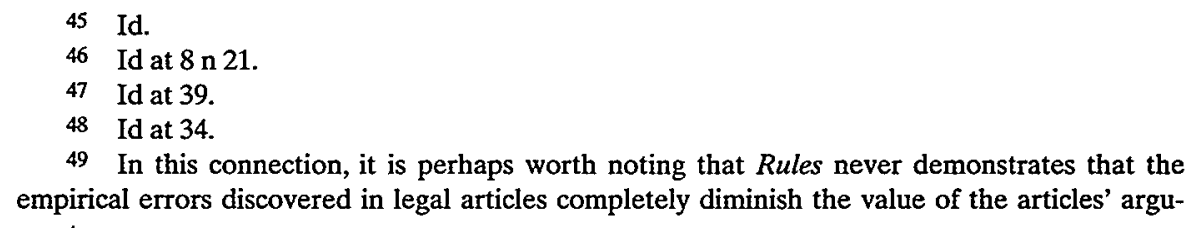

49 In this connection, it is perhaps worth noting that Rules never demonstrates that the empirical errors discovered in legal articles completely diminish the value of the articles' arguments. 
tween accuracy, on the one hand, and timeliness and relevance, on the other. Each department in a university resolves these tradeoffs differently depending on the nature of the discipline, its customs, and, importantly, the demand for the discipline's scholarly output from outside institutions. One reason (but not the only one) why legal scholars sometimes trade accuracy for relevance and timeliness is their close connections to governmental institutions, especially courts, that have to make decisions in the short term under conditions of empirical uncertainty.

Consider Epstein and King's example of the fallacious jury studies that the Supreme Court cited in a 1973 decision holding that sixperson juries satisfy the Seventh Amendment's guarantee of jury trials in civil cases. What Epstein and King overlook is that there was a case to be decided that turned on whether the outputs of six- and twelve-person juries were similar. The three studies they criticize were presumably done in anticipation of this decision. One consequence of Epstein and King's prescriptions is that these studies should not have been published. This means that, in Epstein and King's world, the Supreme Court would have been forced to decide the issue without any scholarly data whatsoever. This is a situation that governmental actors face all the time. They must decide an issue now in the absence of empirical studies that satisfy Epstein and King's rules.

Epstein and King seem committed to the view that such decisions are better made on the basis of no empirical studies than on the basis of sometimes flawed empirical studies. But Epstein and King have done none of the work that, on their own terms, is needed to support such a drastic public-policy prescription. Any such prescription is questionable on both the case level and the systemic level. On the case level, courts might prefer to navigate with an inaccurate map than with no map at all. On the systemic level, legal scholarship produces timely but sometimes methodologically unsophisticated studies, some of which are accurate and some of which are not. A universal insistence on Epstein and King's version of methodological rigor might require making all studies less timely, thereby eliminating studies that are both timely and accurate. Epstein and King have not shown that the costs of methodological perfectionism are worth incurring in the public-policy realm.

Epstein and King try to sidestep this point by advancing proposals for restructuring the legal academy that would facilitate more timely and accurate empirical studies. But since their proposals do nothing to increase the resources available to the legal academy, the proposals simply transpose the tradeoff to the institutional level. Le- 
gal scholars who spend years studying econometrics and statistics and generating data sets are legal scholars who have foregone training in clerkships and law firms and who enter teaching and scholarship at an older age, having read fewer law cases. To be sure, recent years have seen an increasing (but still small) number of empirically trained scholars enter the legal academy. But it is simultaneously parochial and imperialistic for Epstein and King to assert, without demonstration according to the rules of inference, that the opportunity costs of methodological training are identical in both law schools and Ph.D. programs in political science.

\section{CONCLUSION}

One motivation for Rules and similar political science work critical of legal scholarship appears to be concern about the lack of influence of pertinent political science work on legal scholarship." Although we have not amassed the data needed to assess this claim (nor, by the way, have the political scientists who assert it), ${ }^{52}$ we believe it is misplaced. Political science literature related to voting, apportionment, redistricting, political parties, the budget process, and legislatures has had an enormous impact in the legal world. ${ }^{53}$ Leading theories of legal interpretation have been heavily influenced by political science work in social choice and positive political theory. The same is true of the work of many leading constitutional theorists. ${ }^{35}$ And various international relations theories from political science have had an enormous impact on international law scholarship during the past decade. ${ }^{36}$

In short, political science appears to be enjoying great success in the legal academy. A large part of this success is no doubt attributable to insights garnered by political science's distinctive methodological

51 See id at 16-17; Gerald N. Rosenberg, Across the Great Divide (between Law and Political Science), 3 Green Bag 2d 267, 272 (2000).

52 Epstein and King and the Rosenberg piece cited in the previous footnote offer only anecdotal support for their claims.

53 See, for example, Samuel Issacharoff and Richard H. Pildes, Politics as Markets: Partisan Lockups of the Democratic Process, 50 Stan L Rev 643 (1998); Elizabeth Garrett, Rethinking the Structures of Decisionmaking in the Federal Budget Process, 35 Harv J on Legis 387 (1998).

54 See, for example, William N. Eskridge, Jr. and John Ferejohn, The Article I, Section 7 Game, 80 Georgetown L J 523 (1992); Frank H. Easterbrook, The Role of Original Intent in Statutory Construction, 11 Harv J L \& Pub Pol 59 (1988).

55 See, for example, Cass R. Sunstein, Free Markets and Social Justice (Oxford 1997); Mark Tushnet, Foreword: The New Constitutional Order and the Chastening of Constitutional Aspiration, 113 Harv L Rev 29 (1999); Bruce Ackerman, The New Separation of Powers, 113 Harv L Rev 633 (2000); Michael J. Klarman, Rethinking the Civil Rights and Civil Liberties Revolutions, 82 Va L Rev 1 (1996).

56 See, for example, Anne-Marie Slaughter, Andrew S. Tulumello, and Stephan Wood, International Law and International Relations Theory: A New Generation of Interdisciplinary Scholarship, 92 Am J Intl L 367 (1998). 
approaches. It does not follow, however, that the legal academy should embrace Epstein and King's normative prescriptions. Political scientists' influence has and will continue to come naturally-not wholesale, through the imperial command of the "Rules of Inference," but rather piecemeal, through the intellectual leakage across disciplinary boundaries of ideas that lawyers find persuasive. 


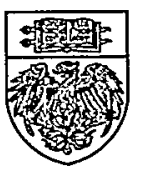

